\title{
Think-Pair-Share strategy in speaking skill development
}

Estrategia de enseñanza Think-Pairs-Share (TPS) en el desarrollo de la habilidad del habla

1 Mónica Jisela Lascano Pérez Universidad Técnica de Ambato, Centro de Idiomas. Ambato, Tungurahua, Ecuador. mj.lascano@uta.edu.ec

3 Sonnia Paulina Altamirano Carvajal iD https://orcid.org/0000-0003-0926-9252 Universidad Técnica de Ambato, Centro de Idiomas. Ambato, Tungurahua, Ecuador. sonniapaltamiranoc@uta.edu.ec

Artículo de Investigación Científica y Tecnológica Enviado: 24/12/2021

Revisado: 29/12/2021

Aceptado: $12 / 01 / 2022$

Publicado:08/03/2023

DOI: https://doi.org/10.33262/concienciadigital.v6i1.4.2039

Cítese:

Lascano Pérez, M. J., \& Altamirano Carvajal , S. P. (2023). Think-Pair-Share strategy in speaking skill development . ConcienciaDigital, 6(1.4), 898-917. https://doi.org/10.33262/concienciadigital.v6i1.4.2039

CONCIENCIA DIGITAL, es una Revista Multidisciplinar, Trimestral, que se publicará en soporte electrónico tiene como misión contribuir a la formación de profesionales competentes con visión humanística y crítica que sean capaces de exponer sus resultados investigativos y científicos en la misma medida que se promueva mediante su intervención cambios positivos en la sociedad. https://concienciadigital.org

La revista es editada por la Editorial Ciencia Digital (Editorial de prestigio registrada en la Cámara Ecuatoriana de Libro con No de Afiliación 663) www.celibro.org.ec

Ciencia Digital (c) (1) (2)(2)

Esta revista está protegida bajo una licencia Creative Commons Attribution Non Commercial No Derivatives 4.0 International. Copia de la licencia: http://creativecommons.org/licenses/by$\underline{\text { nc-nd/4.0/ }}$ 
Palabras claves: aprendizaje profundo, rutas turísticas, clústeres, KMeans, clima
Resumen

Introducción: El dominio de la expresión oral es un poderoso factor de desarrollo del pensamiento estructurado y de las capacidades cognitivas. Sin embargo, las metodologías tradicionales de enseñanza del inglés, basadas en la gramática y la escritura, determinan un bajo rendimiento de los alumnos en el contexto internacional. El Think-Pair-Share (TPS) como estrategia de aprendizaje colaborativo es una herramienta adecuada para resolver el problema. Objetivo: La presente investigación analiza la influencia de la estrategia de enseñanza TPS en el desarrollo de la competencia oral de los estudiantes A1 de un centro de idiomas de una universidad de Ambato, Ecuador. Metodología: A partir de una observación directa y la aplicación de una encuesta, se detectó que los alumnos presentaban dificultades para construir una comunicación eficaz. Se planteó un estudio cuasi experimental, en el que se establecieron dos grupos, control y experimental. El primer grupo recibió clases a través de estrategias de aprendizaje tradicionales y el segundo mediante estrategias basadas en TPS. Inicialmente, se evaluó el nivel de competencia oral de ambos grupos mediante la aplicación del Key English Test (KET) de Cambridge. Las estrategias de enseñanza se aplicaron en ambos grupos. En el caso del grupo experimental, la estrategia TPS consistía en el trabajo colaborativo entre los alumnos, cada participante subía vídeos cortos en una plataforma online sobre sus ideas respecto a los temas sugeridos por el profesor. A continuación, los alumnos revisaron el material preparado por sus compañeros de clase, hicieron sugerencias para mejorar su capacidad de expresión oral y realizaron una presentación oral ante sus compañeros. Se aplicó otra prueba KET para conocer el desarrollo de la capacidad de expresión del habla. Resultados: Los estudiantes mejoraron su rendimiento, aunque el grupo experimental mostró mejores resultados, hasta el punto de que la media fue de 12,48 sobre 15, frente a la media del grupo de control, que fue de 9,70 sobre 15 . Conclusiones: Los estudiantes estaban bien dispuestos a trabajar utilizando la estrategia TPS y el programa de enseñanza permitió a los estudiantes mejorar sus habilidades orales para comunicarse en el idioma inglés. 
Keywords: grammar and vocabulary, interactive communication, pronunciation, speaking skill, Think-pair-share.

\section{Abstract}

Introduction: Mastery of oral expression is a powerful factor in the development of structured thinking and cognitive abilities. However, the traditional methodologies of English teaching, based on grammar and writing, determine a poor performance of students in the international context. Think-pair-share (TPS) as a collaborative learning strategy is an appropriate tool to solve the problem. Objective: This research analyzes the influence of the TPS teaching strategy in the speaking skill development of A1 students at a language center in a university in Ambato, Ecuador. Methodology: From direct observation and the application of a survey, it was detected that the students presented difficulties in constructing effective communication. A quasi-experimental study was considered, in which two groups, control and experimental, were established. The first group received classes through traditional learning strategies and the second through strategy based on TPS. Initially, the oral proficiency level of both groups was evaluated by applying the Cambridge Key English Test (KET). The teaching strategies were implemented in both groups. In the experimental group case, the TPS strategy consisted of collaborative work among students, each participant uploaded short videos in an online platform about their ideas regarding topics suggested by the teacher. The students then reviewed the material prepared by their class partners, made suggestions for improving their speaking skills, and gave an oral presentation to their classmates. Another KET test was applied to know the speaking skill development. Results: Students improved their performance, although the experimental group showed better results, to the point that the mean was 12.48 out of 15 , compared to the mean of the control group, which was 9.70 out of 15 . Conclusion: The students were well disposed to work using the TPS strategy and the teaching program allowed the students to improve their speaking skills to communicate in the English language.

\section{Introduction}

From classical philosophy with Socratic maieutic method to modern linguistics and the contributions of Chomsky's generative grammar, different studies have led to point out 
the key role of spoken language in the learning process. In this context, the process of learning a foreign language is not exempt from this powerful relationship. This is exemplified by the fact that the most representative studies on the dynamics of learning a second language emphasize the high relationship between the development of oral expression skills and good results in learning a new language (Balboni, 2018).

Based on this strong notion, innovations in English language teaching pedagogy have produced important research aimed at determining key strategies for enhancing students' speaking skills to improve English language teaching outcomes. At present, most of the research focused on these efforts agrees that Think-pair-share (TPS) as a collaborative learning strategy is the most appropriate for this purpose. This strategy has shown unexpected effects since, in addition to promoting active student learning, they help build positive relationships in the classroom, thus facilitating the learning environment.

Among the Cooperative Learning Strategies that are best positioned to obtain good results in improving speaking skills in English language learners, the TPS strategy is the one that has demonstrated positive results. This is also a result of the few resources it requires and inherent flexibility that allows it to adapt not only to students of all levels but also to different purposes within the development of language skills (Oviedo \& Mena, 2021).

TPS strategy has therefore been successfully implemented in many countries abroad, especially in Southeast Asia and the Middle East countries, where the remarkable development of their economies has had an impact on the need for students to acquire English language skills at an early age. The great success of the TPS strategy has determined the development of several investigations that take the lead in trying to include this important type of activities within the classroom, not only for the improvement of speech skills but in multiple fields (Ochoa et al., 2016; Tayo \& Hernandez, 2017; Nievecela, 2019; Benalcázar, 2019).

On the other hand, in Ecuador, traditional methodologies of English teaching determine a poor performance of students in the international context (Cronquist \& Fiszbein, 2017). Likewise, students in the A1 English level at a language center of a university in Ambato show a low level of their speaking skills, showing repetitive errors in vocabulary, little fluency, and shyness in expressing their ideas (Tayo \& Hernandez, 2017). Furthermore, the rules of social distancing and confinement as a result of the worldwide pandemic have led to changing educational conditions and created the need to establish new virtual education systems. This has posed new challenges for societies with a marked technological lag.

In view of this and based on the above mentioned, the present research aims to study whether the application of the TPS strategy contributes to the development of the 
speaking skills of A1 students in an English learning program. Whereas this is expected to have positive and measurable results due to the experience of similar research.

The completion of this research allowed to evaluate the teaching strategy implemented in the English language program, which have serious deficiencies and a great need to be rethought. In the same way, this evaluation was carried out against the results of new trends in English language teaching, which represents an opportunity for the institution to update its practices following the example of the education centers with the best results in English language teaching in the world.

In this sense, the present work constitutes an important contribution to support the application of TPS strategy in the speaking skill development of learners of English as a second language. The work is feasible given that the resources for the development of the research are available. In addition, the line of research is framed in the field of interest of teaching English, so it is an opportunity to know the effectiveness of the TPS strategy in practical cases.

According to the context, the problem statement is worded as follows: How can ThinkPair-Share based teaching strategy be applied to the speaking skill development in A1 level students?

\section{Theorical Framework}

Speaking is one of the most important skills that is developed during the learning of a language, whether it is the mother tongue or a second language. This ability is vital since it determines the ability to share ideas or opinions using the structures and concepts of the language. This process is important and significant for learning because it leads the interlocutor to appropriate these notions and knowledge as he interacts with the listeners through speech (Zaim \& Radjab, 2004).

The mastery of the ability of speech is a priority in the teaching of a second language. Consequently, a large part of classroom teaching strategies should focus on developing oral proficiency and accustoming the student to their regular practice. This relevance can be seen in the fact that the success of learning English is generally associated with the ability of students to communicate fully with the native English speaker or with English speakers with some expertise. This criterion is common even though there are actually four skills related to English proficiency (Richards, 2008).

However, for the majority of students of English as a second language (ESL), the task of speaking becomes extremely difficult. This situation determines that although students have dedicated several years to learning the English language, they have deficiencies and shyness when expressing themselves orally. The presence of the English language has been increasing in every aspect of everyday life simultaneously with the process of 
globalization and collectivization of information technologies. This leads to a strong trend that pushes people to acquire more and more knowledge of the English language through the information they receive from the world. This trend in turn motivates them to develop their skills in relation to the use of English as a tool to appropriate the global culture (Schunk, 2012).

Motivation is an element that cannot be neglected as an important factor in the development of speaking skills and language learning. Liu (2010) states that when students feel motivated, they try harder to express themselves, which constitutes motivation as an incentive for action. Harmer (2001) explains that motivation is physiologically translated into excitation or impulse that initiates cognitive and motor processes that lead to notable improvements in speech abilities. In this sense, other authors as Liu (2010) complement the statements of Harmer and postulating that motivation determines the cognitive behaviors and processes that allow achieving goals in the development of any of the linguistic abilities, not only in relation to speech ability (Schunk, 2012).

Coyle (2014) says there are two factors that are decisive in the successful development of speaking skills when learning ESL, one is the motivation and the other is a positive classroom environment, since they encourage students to actively participate in the learning process, which greatly facilitates the task of teaching. Utama et al. (2013) affirm that the correct use of speech requires two criteria to be taken into account. First, the linguistic criterion that implies guiding oneself by grammar, making understandable statements, taking care of pronunciation, choosing a correct vocabulary, speaking at an adequate speed, and constructing sentences that are not too long. Whereas, the nonlinguistic criterion implies dimensions related to personality such as self-esteem and extroversion, necessary for the speaker to exercise the linguistic aspects. In order to achieve success in speech development, students must meet the criteria of linguistic and non-linguistic correctness.

A fundamental aspect of the development of speech in the process of teaching the English language is interaction, that is, the interactions of the student using the language and the notions learned. Macpherson (2007) points out that the learning process in these strategies has to be cooperative and socially based because students work collectively sharing ideas and comments about the learning process in class. This quality determines that cooperative learning strategies are identified as resources that develop critical thinking in students while actively participating in the construction of the learning process (Devi et al., 2015).

The TPS strategy is one of the cooperative learning strategies (CLS) for the joint construction of knowledge, where the controversy and the exchange of opinions between the pairs are established, to finally share their position with convincing arguments. The 
TPS is a cooperative learning strategy because students work in pairs and share their ideas with the whole class. Therefore, they build knowledge based on the reasoning and organization of their ideas. This strategy represents an excellent opportunity for students to develop critical and creative thinking skills, which generates significant learning because they share ideas, reflect, and show their ingenuity (Raba, 2017).

Sanjani (2015) defines some advantages of the use of CLS and TPS, for example students are encouraged to continue learning beyond the classroom due to the positive experience in the workgroups, encourages teamwork, promote more pleasant work environments, promotes student participation, reduces discipline problems since the active role of the student makes it less disruptive, facilitates the work of the teacher since the active participation of the student improves their retention. The value of this strategy is that they remove the teacher from the center of the learning process and build a cooperative process that is reinforced from the interactions between the teacher and the students (Suwandi \& Taufiqullah, 2009).

The TPS strategy is developed in three steps or phases: the thinking phase (individual work), discussion phase (pair work), and sharing phase (group work). It is also designed to develop the ability to process information, formulate ideas and conclusions while helping students understand the concepts of specific topics, also allows the student to develop critical thinking by taking into consideration different points of view. Its wide use for different purposes is due in large part to the fact that it is easy to prepare and apply, the interactions motivate students, they can be formulated around different topics according to the level of the students and the teacher can better understand the process of learning by listening to couples interacting (Devi et. al., 2015).

The first step consists of thinking, students have to reason about a question or problem posed by the teacher, they are assigned a certain amount of time so that they can organize their ideas individually and then argue about those ideas (Raba, 2017).

The next step is to work in pairs, asking the students to exchange opinions and discuss the topic or question with their respective partners. It is a space for them to reflect, as well as to reaffirm their knowledge. They are given enough time to share ideas and come up with solutions (Utama et al., 2013).

The third and last strategy step is for students to share the ideas and conclusions they reached about the proposed question. It is an opportunity for each pair to express themselves. This way of working not only encourages oral communication but also encourages the development of thinking (Raba, 2017). Figure 1 provides a summary of the main ideas regarding the phases of the TPS: 


\section{Figure 1}

Illustration of the TPS phases

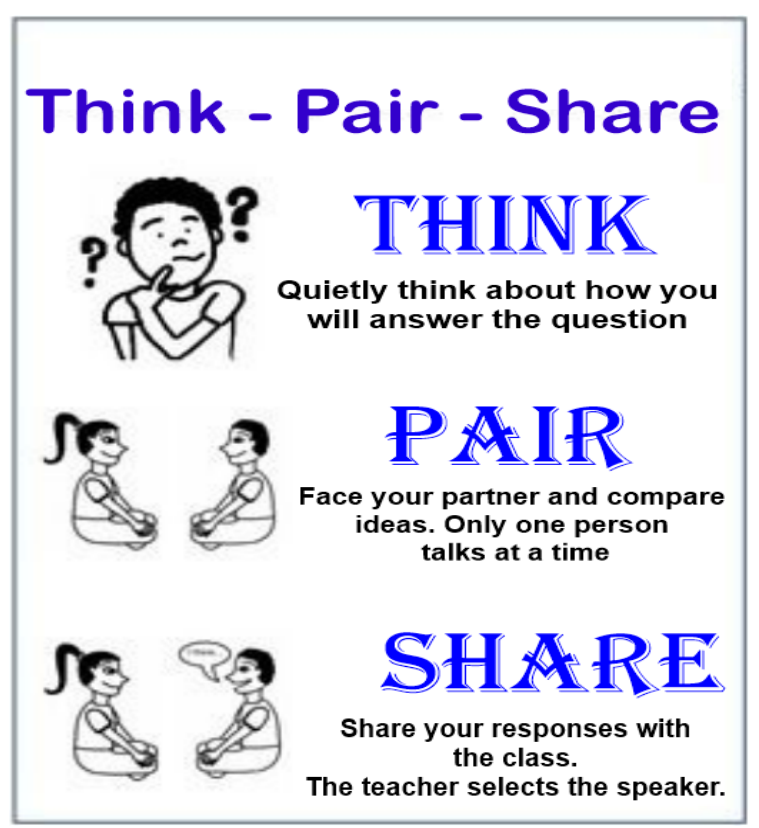

\section{Methodology}

Research, universe and sample

The development of the research used a quasi-experimental design and comprises the initial evaluation (pre-test) of the speaking skill in the English language of A1 students from an English language program. The focus of this research is quantitative that according to Arikunto (2002), is characterized by the use of figures as well as the collection of data for processing and interpretation in order to obtain measurable results. This approach is materialized in the information analysis instrument of the research that uses statistical methods to determine technically and scientifically the effect of applying TPS in the speaking skill development.

The research uses a quasi-experimental design for the evaluation of groups pre-test and post-test that are also framed in a quantitative context. The information analysis instrument and experimental design are common in recent indexed research on the subject, which allows approaching the subject with rigorous research and current analysis tools.

The population in this research was the A1 level students in an academic period of five months. The sample was made up by employing the random cluster sampling, applied to the A1 level parallels and not to the students. Two groups of students were established, 
one called control and the other experimental. The quasi-experimental design of the research was applied only to the experimental group and the control group worked with the traditional teaching methodology. The samples consisted of 62 students in which 32 students were part of the experimental group and 30 students in the control group.

The TPS strategy was applied in the experimental group for a given period, while the control group followed the traditional class planning. After this, the post-test was applied in both groups with the same collect data tools and covering the same fields. Finally, a qualitative analysis of the results of the learning environment and a statistical quantitative analysis of the data obtained from the speaking test was carried out. The statistical analysis was performed using the student t-test for paired samples. The objective was to determine if there has been a change in the performance of the speaking skills of the experimental group versus the control group.

\section{Instruments and variables}

The instrument used in this research was an oral evaluation based on a rubric that identifies the main aspects of speaking ability. This tool was applied in both the experimental and control groups. The assessment was used to measure the speaking skill of the experimental and control groups before and after the application of the TPS strategy. This allowed to have the data for the statistical analyzes to answer the research questions. The evaluations were made to each of the members of the experimental and control groups through the Zoom platform, using the same format for both pre-test and post-test diagnosis. The evaluation was based on the Cambridge Key English Test (KET) format, in accordance with its content, application parameters and evaluation rubric.

In this assessment, students participated in a conversation answering and asking simple questions. The oral ability assessment took place face to face with two candidates and two examiners. The teacher assessed the student's speaking skills and assigned a total grade corresponding to performance in specific basic aspects, as determined by the Cambridge KET exam evaluation rubric. These aspects were: grammar and vocabulary, pronunciation, and interactive communication which represent highly significant aspects of speech that allows a comprehensive evaluation of the fundamental fields to measure the development of the oral ability of each student. In addition, to obtain a more precise evaluation of the speaking skill of the students in both groups, in the pre-test and the posttest, a requalification of the same was carried out by another collaborating teacher of the English language.

\section{Materials and TPS lesson plans}

The application of the TPS strategy was proposed by the research teacher to the students of level A1, during class hours on the virtual Flipgrid platform and zoom. In parallel to 
this application, research will be carried out to determine the effect of the application of the cooperative teaching TPS strategy on the development of students' speaking skills.

Taking into account the fact that the classes for the students were developed virtually through the Zoom platform due to Covid-19, the TPS strategy was adapted, so that it can be carried out in the sessions of virtual classes, reinforcing the learning of the contents and at the same time being suitable for the A1 level of the students. The researchers prepared the lessons and worked on materials of the TPS strategy using the contents already reviewed according to the syllable. The implementation of the strategy was planned for fifteen daily sessions over the course of a month.

The proposal implementation required some short videos responses and present the developed topic to the class. Subsequently, the application of the strategy was developed as follows: Students worked in pairs. In each session of the application of the strategy, the materials for the development of the strategy were shared with the working groups through Flipgrid platform, consisting of a worksheet which contains the question or problem with images that originates a debate.

Next, the researchers made sure that the working pairs understood the assigned material and the task to be carried out. The students carried out the strategy in the way indicated by the researchers, generating two products; first a video where each student exposed about the topic, and after a video with suggestions to the partner about the topic. Both videos were uploaded in the Flipgrid platform. The students made an oral exposition in pairs about the topic in class through the Zoom platform. And finally, the researchers and students commented about the grammar, vocabulary, and pronunciation errors founded in their partners' expositions.

The application of the TPS methodology is carried out through 15 lessons for the development of the educational proposal. The activities developed for the implementation of the TPS strategy are the following:

\section{Stage 1: Think}

- The teacher develops the content of the lessons, indicating the topic and the main ideas that the students have to work on, the discussion questions regarding the topic, the vocabulary to be used, and the complementary reinforcement activities. In addition, she accompanies the lesson with suggestive images of the topic. For this purpose, a text document is created and uploaded to the Flipgrid platform.

- Students have to work in pairs.

- Each student must review the content of the lesson, identify the topic, and recognize the images presented to them. 
- Student A records a short video talking about his/her thoughts on the lesson topic and uploads it to the Flipgrid platform.

- Student B also records a short video talking about his/her thoughts on the lesson topic and uploads it to the Flipgrid platform.

Stage 2: Pair

- Student A watches his/her partner's video and writes a comment in the Flipgrid platform about the partner's speech, taking into account the content, grammar, vocabulary, and pronunciation.

- Student A records a short video in which makes suggestions to his/her partner about the topic and upload it in the Flipgrid platform.

- Student B also watches his/her partner's video and writes a comment in the Flipgrid platform about the partner's speech, taking into account the content, grammar, vocabulary, and pronunciation.

- Student B also records a short video in which makes suggestions to his/her partner about the topic and upload it in the Flipgrid platform.

- Teacher should check that all students have uploaded their videos.

\section{Stage 3: Share}

- Teachers present a lesson topic in class through the Zoom platform.

- Each pair of students make a short speech in class about the topic directed to their classmates.

After all students end the intervention, everyone should debate observations about their classmates' speeches in which they give opinions about the grammar, vocabulary, pronunciation, and interactive communication development of their classmates.

\section{Results and Discussion}

The goal of this research was to measure the effects of the TPS strategy in the speaking skill development in A1 students. According to the KET test, the speaking skill has three criteria: grammar and vocabulary, pronunciation, and interactive communication. In this sense, the results were presented and analyzed for each case. table 1 presents the results of the pre-test and post-test in the control group and table 2 the results of the experimental group: 
Table 1

Pre-test and Post-test results for the control group

\begin{tabular}{|c|c|c|c|c|c|c|c|c|}
\hline \multirow{2}{*}{$\begin{array}{l}\text { CG } \\
\text { No. }\end{array}$} & \multicolumn{4}{|c|}{ Pre-Test } & \multicolumn{4}{|c|}{ Post-Test } \\
\hline & G\&V & $\mathbf{P}$ & IC & General & G\&V & $\mathbf{P}$ & IC & General \\
\hline 1 & 2.5 & 3.0 & 2.0 & 7.5 & 3.5 & 4.0 & 3.0 & 10.5 \\
\hline 2 & 2.5 & 3.5 & 2.5 & 8.5 & 4.0 & 4.5 & 3.0 & 11.5 \\
\hline 3 & 3.0 & 2.5 & 3.0 & 8.5 & 3.5 & 2.5 & 3.0 & 9.0 \\
\hline 4 & 3.0 & 3.0 & 1.0 & 7.0 & 3.5 & 3.5 & 2.0 & 9.0 \\
\hline 5 & 2.0 & 1.5 & 2.0 & 5.5 & 2.0 & 3.0 & 1.5 & 6.5 \\
\hline 6 & 2.0 & 1.5 & 1.5 & 5.0 & 2.5 & 2.5 & 2.0 & 7.0 \\
\hline 7 & 3.0 & 2.5 & 1.5 & 7.0 & 3.5 & 3.0 & 3.0 & 9.5 \\
\hline 8 & 2.0 & 3.0 & 3.0 & 8.0 & 3.0 & 2.5 & 4.0 & 9.5 \\
\hline 9 & 2.0 & 2.5 & 1.5 & 6.0 & 3.0 & 2.5 & 3.0 & 8.5 \\
\hline 10 & 3.0 & 3.5 & 4.0 & 10.5 & 3.0 & 4.0 & 4.5 & 11.5 \\
\hline 11 & 3.0 & 3.0 & 3.5 & 9.5 & 3.5 & 3.5 & 3.0 & 10.0 \\
\hline 12 & 2.0 & 1.5 & 2.0 & 5.5 & 3.5 & 3.0 & 3.0 & 9.5 \\
\hline 13 & 1.5 & 2.5 & 2.5 & 6.5 & 2.0 & 3.5 & 3.0 & 8.5 \\
\hline 14 & 2.0 & 1.0 & 1.5 & 4.5 & 2.0 & 2.0 & 3.0 & 7.0 \\
\hline 15 & 2.5 & 4.0 & 3.0 & 9.5 & 3.5 & 4.0 & 3.0 & 10.5 \\
\hline 16 & 2.5 & 2.5 & 3.5 & 8.5 & 3.0 & 4.0 & 3.5 & 10.5 \\
\hline 17 & 2.5 & 2.0 & 2.5 & 7.0 & 4.0 & 2.5 & 4.0 & 10.5 \\
\hline 18 & 4.0 & 2.0 & 1.5 & 7.5 & 4.5 & 2.0 & 2.0 & 8.5 \\
\hline 19 & 1.5 & 2.0 & 4.0 & 7.5 & 2.5 & 3.0 & 3.5 & 9.0 \\
\hline 20 & 1.5 & 3.5 & 3.0 & 8.0 & 2.5 & 4.0 & 4.0 & 10.5 \\
\hline 21 & 3.0 & 3.0 & 2.0 & 8.0 & 3.0 & 3.5 & 3.0 & 9.5 \\
\hline 22 & 3.5 & 4.5 & 3.5 & 11.5 & 4.5 & 4.0 & 3.0 & 11.5 \\
\hline 23 & 2.5 & 1.5 & 1.5 & 5.5 & 3.5 & 3.0 & 1.5 & 8.0 \\
\hline 24 & 2.5 & 2.0 & 1.5 & 6.0 & 2.5 & 3.5 & 2.5 & 8.5 \\
\hline 25 & 3.0 & 3.5 & 4.0 & 10.5 & 3.5 & 3.5 & 4.0 & 11.0 \\
\hline 26 & 3.0 & 3.5 & 3.0 & 9.5 & 4.0 & 3.5 & 3.5 & 11.0 \\
\hline 27 & 1.5 & 2.5 & 2.5 & 6.5 & 1.5 & 3.5 & 2.5 & 7.5 \\
\hline 28 & 2.0 & 3.0 & 3.0 & 8.0 & 3.5 & 4.0 & 3.5 & 11.0 \\
\hline 29 & 3.0 & 4.0 & 3.0 & 10.0 & 5.0 & 4.5 & 4.5 & 14.0 \\
\hline 30 & 1.5 & 2.5 & 3.5 & 7.5 & 4.0 & 3.0 & 5.0 & 12.0 \\
\hline Mean & 2.45 & 2.68 & 2.55 & 7.68 & 3.25 & 3.32 & 3.13 & 9.70 \\
\hline
\end{tabular}

Note: CG: Control group / G\&V: Grammar and vocabulary / P Pronunciation / IC: Interactive communication. Data extracted from pre-test and post-test KET exam, Speaking section. 
Table 2

Pre-test and Post-test results for the experimental group

\begin{tabular}{|c|c|c|c|c|c|c|c|c|}
\hline \multirow{2}{*}{$\begin{array}{l}\text { EG } \\
\text { No. }\end{array}$} & \multicolumn{4}{|c|}{ Pre-Test } & \multicolumn{4}{|c|}{ Post-Test } \\
\hline & G\&V & $\mathbf{P}$ & IC & General & G\&V & $\mathbf{P}$ & IC & General \\
\hline 1 & 3.0 & 3.0 & 2.0 & 8.0 & 4.0 & 3.5 & 3.5 & 11.0 \\
\hline 2 & 3.0 & 2.5 & 3.0 & 8.5 & 4.5 & 4.0 & 4.5 & 13.0 \\
\hline 3 & 3.0 & 3.5 & 2.5 & 9.0 & 4.0 & 4.0 & 4.5 & 12.5 \\
\hline 4 & 3.0 & 3.5 & 2.5 & 9.0 & 4.0 & 4.5 & 5.0 & 13.5 \\
\hline 5 & 2.5 & 2.0 & 1.5 & 6.0 & 3.5 & 4.0 & 3.5 & 11.0 \\
\hline 6 & 3.0 & 1.5 & 2.5 & 7.0 & 4.5 & 4.0 & 3.0 & 11.5 \\
\hline 7 & 3.0 & 3.0 & 2.5 & 8.5 & 4.5 & 3.5 & 4.5 & 12.5 \\
\hline 8 & 3.5 & 3.5 & 3.0 & 10.0 & 5.0 & 5.0 & 4.0 & 14.0 \\
\hline 9 & 3.5 & 2.0 & 3.0 & 8.5 & 4.5 & 3.5 & 3.5 & 11.5 \\
\hline 10 & 2.5 & 3.0 & 2.5 & 8.0 & 4.5 & 4.0 & 4.5 & 13.0 \\
\hline 11 & 3.0 & 3.0 & 2.5 & 8.5 & 4.0 & 4.0 & 3.5 & 11.5 \\
\hline 12 & 3.0 & 2.5 & 3.0 & 8.5 & 5.0 & 3.5 & 4.0 & 12.5 \\
\hline 13 & 2.5 & 2.0 & 2.5 & 7.0 & 3.5 & 4.5 & 4.0 & 12.0 \\
\hline 14 & 2.5 & 2.0 & 1.5 & 6.0 & 4.0 & 3.5 & 4.5 & 12.0 \\
\hline 15 & 4.0 & 3.0 & 3.0 & 10.0 & 4.5 & 3.5 & 5.0 & 13.0 \\
\hline 16 & 3.5 & 2.5 & 3.0 & 9.0 & 4.0 & 4.0 & 4.0 & 12.0 \\
\hline 17 & 2.5 & 1.5 & 3.0 & 7.0 & 4.0 & 4.0 & 4.0 & 12.0 \\
\hline 18 & 3.5 & 3.0 & 2.0 & 8.5 & 4.5 & 4.5 & 3.5 & 12.5 \\
\hline 19 & 3.0 & 2.5 & 1.5 & 7.0 & 4.0 & 3.5 & 3.0 & 10.5 \\
\hline 20 & 3.0 & 2.0 & 3.0 & 8.0 & 3.5 & 4.0 & 5.0 & 12.5 \\
\hline 21 & 3.5 & 3.0 & 3.5 & 10.0 & 5.0 & 4.5 & 5.0 & 14.5 \\
\hline 22 & 2.5 & 3.5 & 3.5 & 9.5 & 4.0 & 4.0 & 4.5 & 12.5 \\
\hline 23 & 3.0 & 2.5 & 2.5 & 8.0 & 4.0 & 4.5 & 4.5 & 13.0 \\
\hline 24 & 1.5 & 2.5 & 2.5 & 6.5 & 4.5 & 4.0 & 4.5 & 13.0 \\
\hline 25 & 2.5 & 3.0 & 3.5 & 9.0 & 4.5 & 4.5 & 5.0 & 14.0 \\
\hline 26 & 2.5 & 3.0 & 3.0 & 8.5 & 5.0 & 3.5 & 4.5 & 13.0 \\
\hline 27 & 2.5 & 3.0 & 3.0 & 8.5 & 4.0 & 4.5 & 3.5 & 12.0 \\
\hline 28 & 2.5 & 2.5 & 3.0 & 8.0 & 4.0 & 4.5 & 4.0 & 12.5 \\
\hline 29 & 2.5 & 3.0 & 2.5 & 8.0 & 2.5 & 5.0 & 5.0 & 12.5 \\
\hline 30 & 2.5 & 2.5 & 3.0 & 8.0 & 4.0 & 4.5 & 3.5 & 12.0 \\
\hline 31 & 2.0 & 2.0 & 2.5 & 6.5 & 4.5 & 4.0 & 5.0 & 13.5 \\
\hline 32 & 2.5 & 1.0 & 2.0 & 5.5 & 4.5 & 3.5 & 5.0 & 13.0 \\
\hline Mean & 2.83 & 2.59 & 2.64 & 8.06 & 4.20 & 4.06 & 4.22 & 12.48 \\
\hline
\end{tabular}

Note: EG: Experimental group / G\&V: Grammar and vocabulary / P Pronunciation / IC: Interactive communication. Data extracted from pre-test and post-test KET exam, Speaking. 
Table 3

Summary of the means obtained in the pre-test and post-test by groups.

\begin{tabular}{lcccc}
\hline \multirow{2}{*}{ Speaking skill } & \multicolumn{3}{c}{ Group } \\
\cline { 2 - 5 } \multicolumn{1}{c}{ Criterion } & Pre-test mean & Post-test mean & Pre-test mean & Post-test mean \\
\hline Grammar and vocabulary & 2.45 & 3.25 & 2.83 & 4.20 \\
Pronunciation & 2.68 & 3.32 & 2.59 & 4.06 \\
Interactive communication & 2.55 & 3.13 & 2.64 & 4.22 \\
General & 7.68 & 9.70 & 8.06 & 12.48 \\
\hline
\end{tabular}

Note: Data extracted from Pre-test and post-test KET exam, Speaking section.

According to the information presented in table 3, the average grades obtained by the students on the post-tests for all criteria were higher than those on the pre-tests in both the control and experimental groups. Whereas figure 2 shows that there is a wide dispersion between the maximum and minimum grades, except for the post-test results of the experimental group, where the range of the data is smaller. This situation implies that the scores in the experimental group tended to be more uniform related to those in the control group. Therefore, the TPS strategy was beneficial, as it allowed all students to improve their speaking skill.

\section{Figure 2}

Boxplot, pre-test and post-test grades by groups

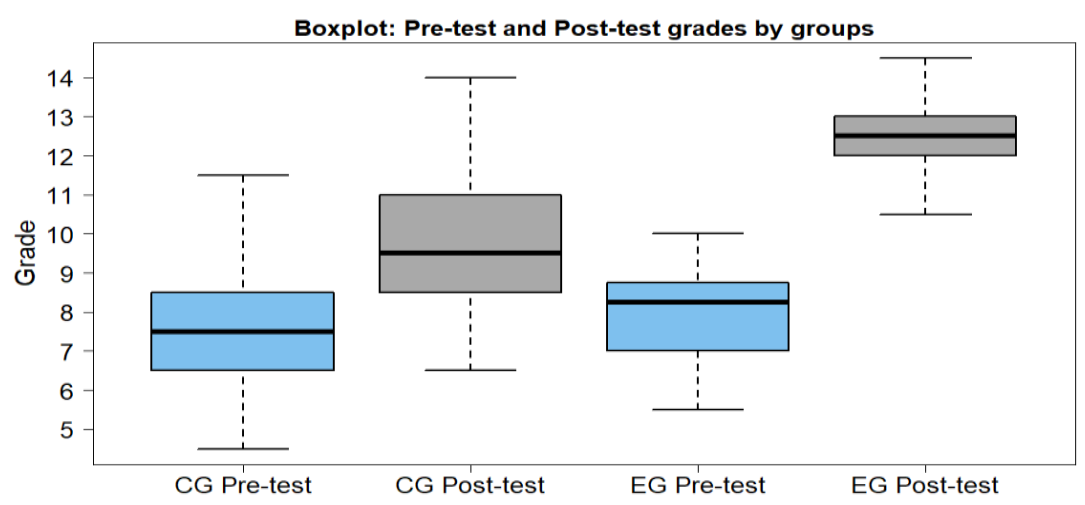

Note: EG: Experimental group / CG: Control group. Data extracted from Pre-test and post-test KET exam, Speaking section.

A statical test was necessary to apply to measure the influence of the think-pair-share strategy in the speaking skill development in A1 students from the English language program. In this sense, an alternative hypothesis was established as well as a null one comes up by default. The purpose was to determine whether the null hypothesis could be 
rejected and the alternative one accepted according to the data obtained from the pre-test and post-test.

\section{Alternative hypothesis}

TPS strategy influences the speaking skill development of A1 students.

A paired sample Student t-test corresponds to apply according to the problem conditions in which there are a pre-test and post-test. The mathematical model is shown as follows:

$$
\begin{aligned}
& \mathbf{H}_{0}: \mu_{2} \leq \mu_{1} \\
& \mathbf{H}_{1}: \mu_{2}>\mu_{1}
\end{aligned}
$$

Where:

$\mu_{1}=$ sample mean in the pre-test.

$\mu_{2}=$ sample mean in the post-test.

By virtue of the fact that the grades in the post-test should be higher than ones in the pretest, the significance level belongs to a single-tailed Student t-test. The critical t-value was obtained using two parameters: level of significance $\alpha$ and degrees of freedom. The first is equal to 0.05 , which means $5 \%$, and the second is equal to the amount of data minus one $(n-1)$. Table 4 presents the paired sample statistics which are used to obtain the calculated t:

\section{Table 4}

Paired sample statistics by groups

\begin{tabular}{clcccc}
\hline \multicolumn{2}{c}{ Paired sample statistics } & Mean & $\boldsymbol{n}$ & $\begin{array}{c}\text { Standard } \\
\text { deviation }\end{array}$ & $\begin{array}{c}\text { Standard error of } \\
\text { the mean }\end{array}$ \\
\hline \multirow{2}{*}{ CG } & Pre-test Total & 7.68 & 30 & 1.76 & 0.3213 \\
& Post-test Total & 9.70 & 30 & 1.68 & 0.3067 \\
& Differences (Post-Pre) & 2.02 & 30 & 1.14 & 0.2081 \\
\cline { 2 - 5 } EG & Pre-test Total & 8.06 & 32 & 1.18 & 0.2086 \\
& Post-test Total & 12.48 & 32 & 0.90 & 0.1591 \\
& Differences (Post-Pre) & 4.42 & 32 & 1.14 & 0.2015 \\
\hline
\end{tabular}

Note: EG: Experimental group / CG: Control group. Data extracted from Pre-test and post-test KET exam, Speaking section.

From the data in the table, for the control and experimental groups, the calculated t-values are as follows in Table 5: 
Table 5

Summary of paired sample statistics

\begin{tabular}{clcccc}
\hline Group & \multicolumn{1}{c}{ Test } & $\begin{array}{c}\text { Tabulated } \\
\text { t-value }\end{array}$ & $\begin{array}{c}\text { Calculated } \\
\text { t-value }\end{array}$ & $\begin{array}{c}\text { Degrees of } \\
\text { freedom }\end{array}$ & $\begin{array}{c}\text { Significance } \\
\text { (unilateral) }\end{array}$ \\
\hline CG & $\begin{array}{l}\text { Post-test Total - Pre-test } \\
\text { Total }\end{array}$ & 1.6991 & 9.6824 & 29 & $7 \times 10^{-11 * * * *}$ \\
EG $\begin{array}{l}\text { Post-test Total - Pre-test } \\
\text { Total }\end{array}$ & 1.6955 & 21.8696 & 31 & $1.0538 \times 10^{-20 * * *}$ \\
\hline
\end{tabular}

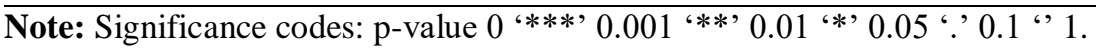

EG: Experimental group / CG: Control group. Data extracted from Pre-test and post-test KET exam, Speaking section.

The calculated t-value in both cases (control and experimental groups) is greater than the critical $\mathrm{t}$-value. The unilateral significance level for the experimental group $\mathrm{p}$-value $=$ $1.0538 \times 10^{-20}$ is lower than $\alpha=0.05(5 \%)$ with 31 degrees of freedom. Likewise, the $t-$ calculated value is equal to 21.8696 and is upper than critical t-value of 1.6955. Therefore, it is located in the null rejection region. It means the null hypothesis is rejected and the alternative one is accepted: "TPS strategy influences the speaking skill development of A1 students".

The results in the post-test are significantly better than the pre-test for both cases (control and experimental groups). However, the post-test mean grade of the control is 9.70 out of 15 , while in the experimental one is 12.48 out of 15 . Consequently, the TPS strategy is efficient to ensure speaking skills development in A1 students. This same trend appears in the results of similar studies (Usman, 2015; Desta, 2017; Nasir, 2018; Tayo \& Hernandez, 2017).

\section{Conclusions}

- A1 students from the English language program showed difficulties in establishing interactive communication in the English language. They also presented grammatical, vocabulary, and pronunciation deficiencies. Students obtained a mean grade of 7.68 and 8.06 out of 15 in the pre-test according to the KET rubric, in the control and experimental groups, respectively.

- It was designed a learning plan of TPS lessons applied in which students made a collaborative work. In this way, the students carried out collaborative work based on the recording of videos. They talked about various topics related to the images uploaded by the teacher to the platform. Subsequently, they reviewed the videos of their peers and made suggestions to improve the oral communication of each of the students. 
- Students obtain better grades in the post-test evaluation about pronunciation, interactive communication, grammar, and vocabulary criterion at the end of the proposal application. Students obtained a mean grade of 9.70 and 12.48 out of 15 , respectively, in the control and experimental groups. The use of the TPS strategy allows students to improve their speaking skills.

\section{Bibliographic References}

Arikunto, S. (2002). Procedure Penelitian Suatu Pendekatan Praktik. Jakarta: PT Rineka Cipta. https://irigasi.info/wp-content/uploads/2021/03/PROSEDUR-PENELITIAN17-Mar-2021-14-11-12.pdf

Balboni, P. E. (2018). A theoretical framework for language education and teaching. Cambridge Scholars Publishing. ISBN (13): 978-1-5275-0869-9. https://www.cambridgescholars.com/resources/pdfs/978-1-5275-0869-9-sample.pdf

Benalcázar, J. (2019). Effects of the CLIL approach in Oral Production of English Students in the Second Year of the United General Baccalaureate at a High school in Cuenca, Ecuador. Revista Boletín Redipe 8(12), 117-128. https://doi.org/10.36260/rbr.v8i12.878

Coyle, D. (2014). Motivating Teachers and Learners as Researchers in "Motivation and Foreign Language Learning: From Theory to Practice”. Amsterdam: John Benjamins Publishing Company. https://abdn.pure.elsevier.com/en/publications/motivating-learners-and-teachers-asresearchers

Cronquist, K., \& Fiszbein, A. (2017). English Language Learning in Latin America. https://www.thedialogue.org/wp-content/uploads/2017/09/English-LanguageLearning-in-Latin-America-Final-1.pdf

Devi, A., Musthafa, B., \& Gustine, G. (2015). Using Cooperative Learning in Teaching Critical Thinking in Reading. English Review: Journal of English Education, 4 (1), 1-14. https://journal.uniku.ac.id/index.php/ERJEE/article/view/310/237

Desta, R. A. (2017). Think pair share technique in teaching speaking skill. Research in English and Education Journal, 2(1), 37-46. http://jim.unsyiah.ac.id/READ/article/view/2597/1432

Harmer, J. (2001). The Practice of English Language Teaching. London: Longman Press. https://www.scirp.org/(S(351jmbntvnsjt1aadkposzje))/reference/ReferencesPapers. aspx?ReferenceID=2636399 
Liu, X. (2010). Arousing the College Students' Motivation in Speaking English through Role-Play. International Education Studies, 3(1), 136-144. https://files.eric.ed.gov/fulltext/EJ1066066.pdf

Macpherson, A. (2007). Cooperative learning group activities for college courses - A guide for instructor. Kwantlen University Collage.

Nasir, A. (2018). The Implementing of Think-Pair-Share (TPS) Strategy in Teaching Speaking Skills. Journal of Advanced English Studies, 1(1), 8-13. http://sastra.unifa.ac.id/journal/index.php/jes/article/view/7/3

Nievecela, L. O. A. (2019). Using Cooperative Learning Strategies to Develop Rural Primary Students' English Oral Performance. English Language Teaching, 12(11), 74-84. https://www.ccsenet.org/journal/index.php/elt/article/view/0/41116

Ochoa, C., Cabrera, P., Quiñónez, A., Castillo, L., \& Gonzáles, P. (2016). The Effect of Communicative Activities on EFL Learners' Motivation: A Case of Students in the Amazon Region of Ecuador. Colomb. Appl. Linguist. J., 18(2), 39-48. DOI: http://dx.doi.org/10.14483/calj.v18n2.10018

Oviedo, N., \& Mena, J. I. (2021). Communicative language teaching approach in the development of speaking skill. Ciencia Digital, 5(4), 6-26. https://www.cienciadigital.org/revistacienciadigital2/index.php/CienciaDigital/artic le/view/1865

Raba, A. A. (2017). The Influence of Think-Pair-Share (TPS) on Improving Students' Oral Communication Skills in EFL Classrooms. Creative Education, 8(1), 12-23. https://www.scirp.org/pdf/CE_2017011315061631.pdf

Richards, J. (2008). Teaching listening and speaking from theory to practice. Cambridge, UK: Cambridge University Press. ISBN-13 978-0-521-95776-2.

Sanjani, D. (2015). Improving students' speaking ability using think-pair-share of cooperative learning for the 8th grade students of MTsN Karangmojo in the Academic Year of 2014/2015. Published Doctoral Dissertation Yogyakarta State University.

https://eprints.uny.ac.id/23132/1/A\%20Thesis_Erlinna\%20Dewi\%20Sanjani_1020 2241068.pdf

Schunk, D. (2012). Learning Theories: An Educational Perspective. Pearson. http://repository.umpwr.ac.id:8080/bitstream/handle/123456789/96/ [Dale_H._Schunk]_Learning_Theories_An_Educational.pdf?sequence=1 
Suwandi, \& Taufiqullah. (2009). Designing speaking test. Eksplanasi, 4(8), 183-191. https://journal.kopertis6.or.id/index.php/eks/article/view/74/59

Tayo, E., \& Hernandez, E. (2017). Think-Pair-Share (TPS). La técnica de trabajo cooperativo en pares para mejorar la comprensión lectora en la enseñanza del idioma inglés como lengua extranjera. Revista Publicando, 4. 12(1), 361-378, ISSN 13909304. https://revistapublicando.org/revista/index.php/crv/article/view/666

Utama, I. M., Marhaeni, A. A., \& Jaya, I. N. (2013). The Effect of Think Pair Share Teaching Strategy to Students' Self-Confidence and Speaking Competency of the Second-grade students of SMPN 6 Singaraja. Journal Program Pascasarjana, 1(1), 1-10. https://media.neliti.com/media/publications/118338-EN-the-effect-of-thinkpair-share-teaching.pdf

Usman, A. H., \& SH, M. P. (2015). Using the Think-Pair-Share Strategy to Improve Students' Speaking Ability at Stain Ternate. Journal of Education and Practice, 6(10), 37-45. https://files.eric.ed.gov/fulltext/EJ1081679.pdf

Zaim, R., \& Radjab, D. (2004). Improving Students' Speaking Skill by Using Think- PairShare Strategy at the Second Semester of Syariah Class a at Language Center of Uin Suska Riau. Journal English Language Teaching (ELT), 2(1), 1-12. http://ejournal.unp.ac.id/index.php/elt/article/view/4602/3642 
El artículo que se publica es de exclusiva responsabilidad de los autores y no necesariamente reflejan el pensamiento de la Revista Conciencia Digital.

\section{Ciencia
Digital
Eutroul}

El artículo queda en propiedad de la revista y, por tanto, su publicación parcial y/o total en otro medio tiene que ser autorizado por el director de la Revista Conciencia Digital.
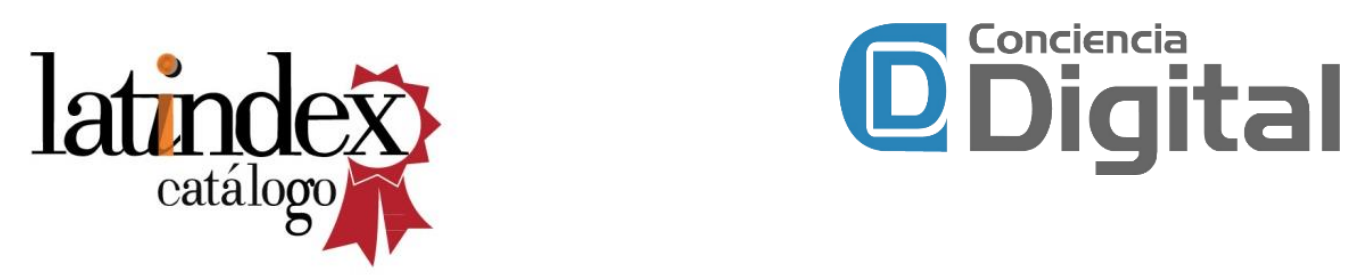

Indexaciones

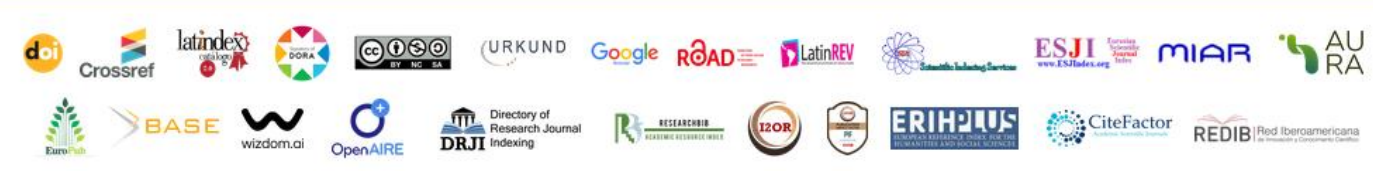

